\title{
Total Synthesis and Biological Evaluation of the Glycosylated Macrocyclic Antibiotic Mangrolide A
}

Hattori, Hiromu ; Roesslein, Joel ; Caspers, Patrick ; Zerbe, Katja ; Miyatake-Ondozabal, Hideki ; Ritz, Daniel ; Rueedi, Georg ; Gademann, Karl

\begin{abstract}
The macrocyclic antibiotic mangrolideA has been described to exhibit potent activity against a number of clinically important Gram-negative pathogens. Reported is the first enantioselective total synthesis of mangrolideA and derivatives. Salient features of this synthesis include a highly convergent macrocycle preparation, stereoselective synthesis of the disaccharide moiety, and two b-selective glycosylations. The synthesis of mangrolide A and its analogues enabled the re-examination of its activity against bacterial pathogens, and only minimal activity was observed.
\end{abstract}

DOI: https://doi.org/10.1002/anie.201805770

Posted at the Zurich Open Repository and Archive, University of Zurich ZORA URL: https://doi.org/10.5167/uzh-157899

Journal Article

Accepted Version

Originally published at:

Hattori, Hiromu; Roesslein, Joel; Caspers, Patrick; Zerbe, Katja; Miyatake-Ondozabal, Hideki; Ritz, Daniel; Rueedi, Georg; Gademann, Karl (2018). Total Synthesis and Biological Evaluation of the Glycosylated Macrocyclic Antibiotic Mangrolide A. Angewandte Chemie Internationale Edition, 57(34):1102011024.

DOI: https://doi.org/10.1002/anie.201805770 


\title{
Total Synthesis and Biological Evaluation of the Glycosylated Macrocyclic Antibiotic Mangrolide A
}

\author{
Hiromu Hattori, ${ }^{[\mathrm{a}]}$ Joel Roesslein, ${ }^{[\mathrm{a}]}$ Patrick Caspers,${ }^{[\mathrm{b}]}$ Katja Zerbe, ${ }^{[\mathrm{a}]}$ Hideki Miyatake-Ondozabal, ${ }^{[\mathrm{a}]}$ \\ Daniel Ritz, ${ }^{[b]}$ Georg Rueedi ${ }^{[b]}$ and Karl Gademann* ${ }^{[a]}$ \\ Dedicated to Professor E. J. Corey on the occasion of his $90^{\text {th }}$ birthday.
}

\begin{abstract}
The macrocyclic antibiotic mangrolide A has been reported to exhibit potent activity against a number of clinically important Gramnegative pathogens. Herein we report the first enantioselective total synthesis of mangrolide A and derivatives. Salient features of our synthesis include a highly convergent macrocycle preparation, stereoselective synthesis of the disaccharide moiety and two $\beta$-selective glycosylations. The synthesis of mangrolide $A$ and its analogues enabled the re-examination of its activity against bacterial pathogens, and only minimal activity was observed.
\end{abstract}

Antimicrobial resistance (AMR) is an increasing serious threat to global public health and the annual loss of life is expected to reach 10 million deaths by 2050 with an economic cost of $\$ 100$ trillion. ${ }^{[1]}$ Effectively addressing AMR requires a multifaceted approach that facilitates sustainable and appropriate use of existing antimicrobials, but also calls for new antibiotics. The development of lead structures with new molecular scaffolds and mechanisms of action thus constitutes an important goal. Particularly, while several antibiotics against infections caused by Gram-negative bacteria are in clinical development today, many constitute modifications of existing antibiotic classes, as the discovery of novel antibiotics that i) can penetrate the outer and inner membrane, and ii) are not subject to extensive efflux remains very challenging.

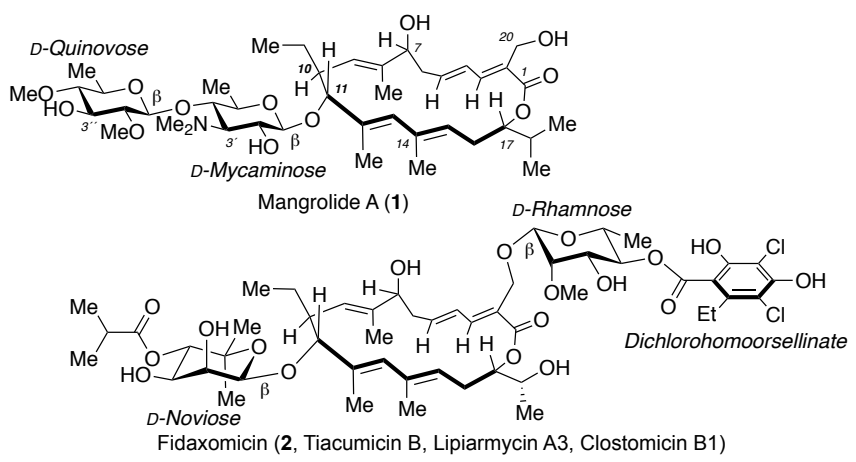

[a] H. Hattori, J. Roesslein, Dr. H. Miyatake-Ondozabal, Dr. K. Zerbe, Prof. Dr. K. Gademann Department Chemistry

University of Zurich

Winterthurerstrasse 190, CH-8057 Zurich

E-mail: karl.gademann@uzh.ch

[b] Dr. P. Caspers, Dr. D. Ritz, Dr. G. Rueedi

Idorsia Pharmaceuticals Ltd

Hegenheimermattweg 91, CH-4123 Allschwil

Supporting information for this article is given via a link at the end of the document. 
Mangrolide A (1) was isolated from the SNA18 strain of Actinoalloteichus sp. following phenotypic screening against Burkholderia cepacia (Figure 1). ${ }^{[2]}$ A preliminary biological study revealed that this natural product is active against Gram-negative bacteria including Acinetobacter baumannii (MIC $=0.25 \mu \mathrm{g} / \mathrm{mL}$ ) and Pseudomonas aeruginosa (MIC $=1.0 \mu \mathrm{g} / \mathrm{mL}$ ). This antibacterial activity has been suggested to involve interaction with the $30 \mathrm{~S}$ subunit of the ribosome leading to mistranslation. ${ }^{[4]}$ Interestingly, fidaxomicin (2), a clinically approved antibiotic against Gram-positive bacteria, shares an almost identical 18-membered macrocyclic scaffold with mangrolide (1), while the carbohydrate and resorcylate moieties are replaced. Most surprisingly, the biological activity and target protein completely changes with these structural alterations from activity against Gram-positive bacteria by RNA polymerase inhibition (for 2) to activity against Gram-negative species by ribosome inhibition (for 1). ${ }^{[4,5]}$ This change of biological properties when switching the molecular decoration of a macrocyclic antibiotic is highly unusual and warrants further studies.

The structure of mangrolide A (1) is characterized by a highly unsaturated 18-membered macrocycle decorated with the unusual carbohydrates, D-2,4-dimethyl quinovose and D-mycaminose, ${ }^{[3]}$ both connected via $\beta$-glycosidic bonds. Synthetic challenges of mangrolide A (1) include (1) the stereoselective construction of the macrocyclic macrocyclic core, ${ }^{[6]}$ (2) the regioselective functionalization as well as the stereoselective synthesis of both carbohydrates and, most importantly, (3) the two $\beta$-selective glycosylation reactions. Despite notable advances in carbohydrate chemistry, methods for the construction of $\beta$ glycosidic bonds of $\mathrm{N}$-alkylamino sugars are rare, ${ }^{[7]}$ although some successful total syntheses of compounds containing this motif have been published. ${ }^{[8]}$ In addition, the $\beta$-selective glycosylation at the sterically demanding $\mathrm{C} 11$ hydroxy group was expected to be challenging based on our earlier experiences in the fidaxomicin synthesis. ${ }^{[6 b]}$ To date, one synthetic study towards mangrolide A (1) has been documented in a patent by De Brabander and co-workers. ${ }^{[4]}$ However, to the best of our knowledge, no total synthesis nor detailed antibiotic testing has been reported, presumably due to the challenging glycosylation chemistry and the complex macrocyclic features. ${ }^{[9]}$ In this communication, we report on the first total synthesis of mangrolide A (1) and on the biological evaluation against bacterial pathogens as well as in vitro mechanism of action studies.

Our retrosynthetic analysis of mangrolide A (1) is illustrated in Scheme 1. Mangrolide A was disconnected at the $\beta$-glycosidic bond expecting that the glycosylation with azidodisaccharide $\mathbf{3}$ and the protected macrocycle $\mathbf{4}$ would proceed with the aid of the neighbouring acyl group. ${ }^{[10]}$ We envisaged that the strategic late-stage $N$-dimethylation of the azide intermediate not only would facilitate smooth glycosidation, but also would provide a key azide analogue to investigate the biological importance of the dimethylamino group (vide infra). The advanced carbohydrate intermediate $\mathbf{3}$ was expected to be synthesized from D-quinovose $\mathbf{5}$ and D-mycaminose precursor 6 by $\beta$-selective glycosylation with the aid of the nitrile effect. ${ }^{[11]}$ Quinovose 5 would be obtained from glycoside 7 and the D-mycaminose precursor 6 from 2-acetylfuran (8) by employing the protocol developed by O'Doherty. ${ }^{[12]}$ The macrocyclic part $\mathbf{4}$ was proposed to be synthesized by ring closing metathesis, Suzuki coupling and Yamaguchi esterification as key steps. ${ }^{[6 a, b]}$

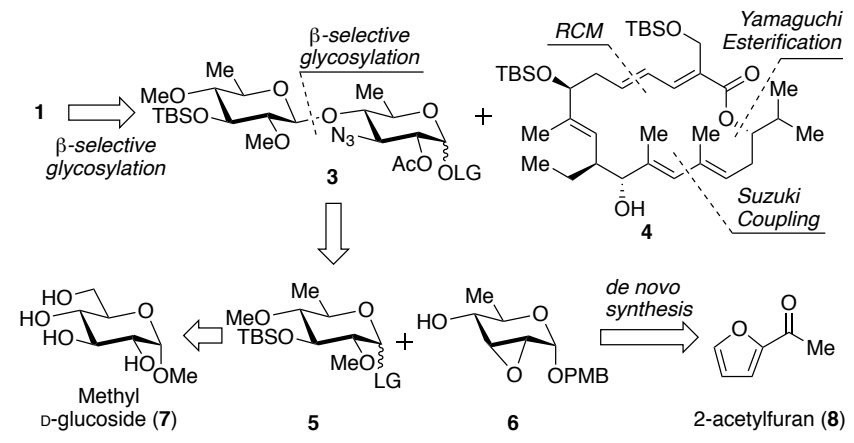

Scheme 1. Retrosynthetic analysis. $\mathrm{LG}=$ leaving group, $\mathrm{PMB}=4$-methoxybenzyl, TBS= tert-butyldimethylsilyl, $\mathrm{RCM}=$ ring-closing metathesis .

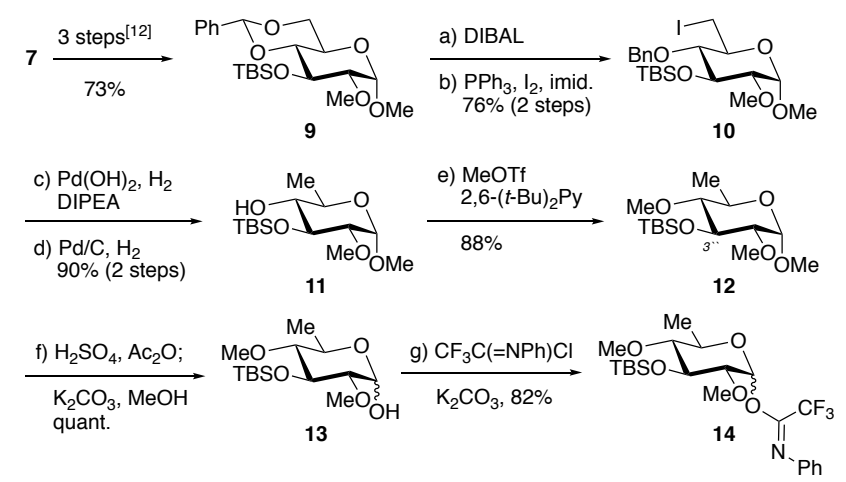

Scheme 2. Synthesis of the quinovose domain 14. Reagents and conditions: a) DIBAL, PhMe, -20 to $\left.10{ }^{\circ} \mathrm{C} ; \mathrm{b}\right) \mathrm{PPh}_{3}, \mathrm{I}_{2}, \mathrm{imid}_{\text {. }}, \mathrm{CH}_{2} \mathrm{Cl}$, reflux, $76 \%$ ( 2 steps); c) $\mathrm{Pd}(\mathrm{OH})_{2}, \mathrm{H}_{2}$ (balloon), DIPEA, MeOH; d) Pd/C, $\mathrm{H}_{2}$ (balloon), MeOH, $90 \%$ (2 steps), e) MeOTf, 2,6- $(t-\mathrm{Bu})_{2} \mathrm{Py}, \mathrm{DCE}(1 \mathrm{M}), 88 \%$; f $\mathrm{H}_{2} \mathrm{SO}_{4}(5 \mathrm{~mol} \%), \mathrm{Ac}_{2} \mathrm{O}$, $0{ }^{\circ} \mathrm{C} ; \mathrm{K}_{2} \mathrm{CO}_{3}, \mathrm{MeOH}$, quant.; g) $\mathrm{CF}_{3} \mathrm{C}(=\mathrm{NPh}) \mathrm{Cl}, \mathrm{K}_{2} \mathrm{CO}_{3}$, acetone, $0^{\circ} \mathrm{C}$ to rt, $82 \%$. DIBAL $=$ diisobutylaluminium hydride, imid. $=$ imidazole, DIPEA $=N, N-$ diisopropylethylamine, $\mathrm{OTf}=$ trifluoromethanesulfonate, $\mathrm{DCE}=1,2$-dichloroethane, $\mathrm{Py}=$ pyridine. 
The synthesis of the quinovose domain began by installing the C2" methyl group and C3" TBS ether onto methyl D-glucopyranoside (7) (Scheme 2). ${ }^{[13]}$ Notably, the sequence was completely selective to give 9 in $73 \%$ over 3 steps including a single chromatographic purification. Selective cleavage of the benzylidene acetal at the $\mathrm{C}^{\prime \prime}$ position ${ }^{[14]}$ followed by iodination ${ }^{[15]}$ gave iodide 10, which was reductively dehalogenated and deprotected to provide quinovose 11. Next, alcohol 11 was treated with a strong methylating reagent MeOTf ${ }^{16]}$ to provide methyl ether 12. Retention of the TBS group at the C3" hydroxy group was confirmed by transformation to the corresponding acetate (TBAF; $\mathrm{Ac}_{2} \mathrm{O}$ ). Acetal exchange under acidic conditions and hydrolysis of the intermediate acetate followed by the imidate addition reaction afforded acetimidate 14, suitable for glycosylation.

Next, we set out to investigate the $\beta$-selective glycosylation with separately synthesized epoxy alcohol $\mathbf{6}^{[12,17]}$ (Scheme 3 ). Various glycosyl donors and activation conditions were examined without success (glycosylfluoride, ${ }^{[18 a]}$ thioglycoside, ${ }^{[18 b]}$ phosphoramidate, ${ }^{[18 c]}$ phosphite ester, ${ }^{[18 \mathrm{~d}]}$ trichloroacetimidate $\left.{ }^{[18 \mathrm{e}, \mathrm{f}]}\right)$. Extensive experimentation revealed that the combination of trifluorophenylacetimidate 14[19] and $\mathrm{Ph}_{3} \mathrm{CB}\left(\mathrm{C}_{6} \mathrm{~F}_{5}\right)_{4}{ }^{[20]}$ in a $n-\mathrm{PrCN} / \mathrm{CH}_{2} \mathrm{Cl}_{2}$ mixture resulted in disaccharide $\beta-15$ in $81 \%$ yield with 4.3 to 1 selectivity in favor of the $\beta$ diastereoisomer. This ratio and yield are worth noting as the selectivity of nitrile assisted glycosylations are generally low in the presence of a silyl group, especially when the C4 hydroxy group of another sugar is employed as the acceptor. ${ }^{[6 b]}$ With careful control of temperature and stirring, this reaction was scaled to gram level. We speculate that the very weak tendency of the bulky tetrakis(pentafluorophenyl)borate anion towards coordination of the oxocarbenium cation ${ }^{[21]}$ contributes to the preferential formation of the $\alpha$-nitrile adduct, which is effectively attacked from the $\beta$ side to form the desired glycosidic bond. To the best of our knowledge, this catalyst system is the first example of $\beta$-glycosylation using acetimidate donors, although the activation of glycosyl fluorides and thioglycosides are well studied by Mukaiyama and co-workers using the same catalyst. ${ }^{[18 a, 22]}$ Next, epoxide opening ${ }^{[17]}$ of disaccharide $\mathbf{1 5}$ using an azide nucleophile was performed and the desired equatorial adduct $\mathbf{1 6}$ was isolated in $80 \%$ yield after acetylation of the resultant $\mathrm{C}^{\prime}$ alcohol. At this stage, the use of the acetate as a protecting group was essential for the separation of the two regioisomers. Deprotection of the PMB group and formation of the imidate afforded donor $\mathbf{1 7}$ as a mixture of anomers $(\alpha / \beta 1: 1)$ in quantitative yield.
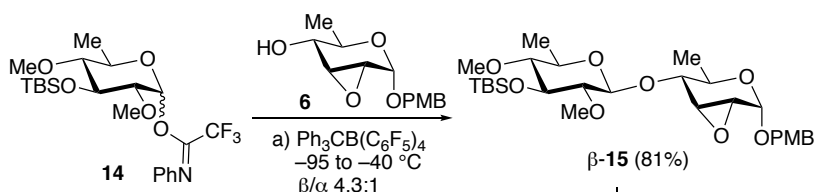

b) $\mathrm{NaN}_{3}$ $\beta / \alpha$ 4.3:1
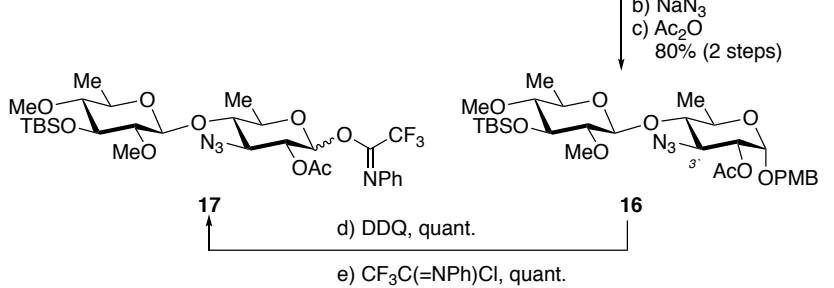

e) $\mathrm{CF}_{3} \mathrm{C}(=\mathrm{NPh}) \mathrm{Cl}$, quant.

Scheme 3. Synthesis of the azidodisaccharide donor 17. Reagents and conditions: a) $\left.14(1.2 \mathrm{eq}), \mathrm{Ph}_{3} \mathrm{CB}_{(} \mathrm{C}_{6} \mathrm{~F}_{5}\right)_{4}(5 \mathrm{~mol} \%), \mathrm{MS} 3 \AA$, $n-\mathrm{PrCN}_{2} / \mathrm{CH}_{2} \mathrm{Cl}_{2}=$ $1: 5,-95$ to $\left.\left.\left.-40{ }^{\circ} \mathrm{C}, 4 \mathrm{~h}, \beta / \alpha 4.3: 1,81 \%(\beta) ; \mathrm{b}\right) \mathrm{NaN}_{3}, \mathrm{NH}_{4} \mathrm{Cl}, \mathrm{EtOH}, 80{ }^{\circ} \mathrm{C} ; \mathrm{c}\right) \mathrm{Ac}_{2} \mathrm{O}, \mathrm{Et}_{3} \mathrm{~N}, \mathrm{DMAP}, 80 \%(2 \mathrm{steps}) ; \mathrm{d}\right) \mathrm{DDQ}, \mathrm{CH}_{2} \mathrm{Cl}{ }_{2}, \mathrm{pH}_{7} \mathrm{phosphate}$ buffer, quant.; e) $\mathrm{CF}_{3} \mathrm{C}(=\mathrm{NPh}) \mathrm{Cl}, \mathrm{K}_{2} \mathrm{CO}_{3}$, acetone, $0{ }^{\circ} \mathrm{C}$ to rt, quant. $\mathrm{MS}=$ molecular sieves, DMAP $=4-($ dimethylamino)pyridine, $\mathrm{DDQ}=2,3-$ dichloro-5,6-dicyano-1,4-benzoquinone.

Having synthesized the azidodisaccharide donor 17, we set about the final assembly starting with macrocycle preparation (Scheme 4). Suzuki coupling ${ }^{[6 b, c]}$ of previously synthesized iodide $18^{[6 a, f]}$ and separately prepared boronate $1^{[23]}$ provided the desired alcohol in excellent yield. This synthetic intermediate was then converted into the corresponding linear polyene 22 through Yamaguchi esterification with acid 20. ${ }^{[6 a, f]}$ A ring-closing metathesis reaction with second generation Grubbs catalyst and subsequent hydrolysis of the nitrobenzoate ester at $\mathrm{C} 11$ afforded alcohol 4 as a mixture of $(E, E)$ and $(E, Z)$ isomers. Fortunately, these stereoisomers could be successfully separated after the TMS protection, and the subsequent silyl deprotection gave access to the pure $(E, E)$ isomer. Next, azide donor $\mathbf{1 7}$ was reacted with macrolactone $\mathbf{4}$ using TBSOTf as an activator. To our surprise, the reaction proceeded smoothly to provide the desired $\beta$-isomer in $42 \%$ yield with complete selectivity. This yield was striking given that the glycosylation of such a hindered system could never be achieved on a related system in our previous fidaxomicin synthesis. ${ }^{[6 b, 6 f]}$ The key to this success is attributed to higher stability ${ }^{[2]}$ and less steric hindrance of the rationally designed glycosyl donor. In addition, the use of the azide donor was essential, as a model study using various glycosyl donors with the $N, N$-dimethylamino group and different activation conditions never resulted in the desired product in acceptable yield. 


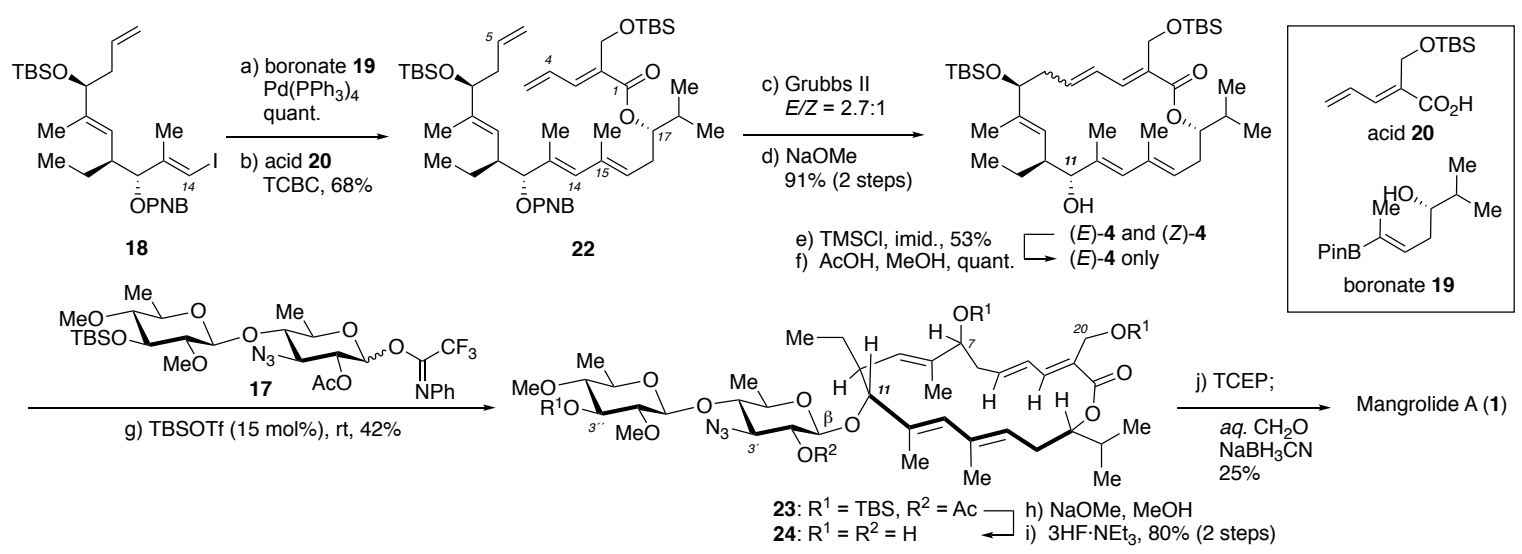

Scheme 4. Total synthesis of mangrolide A (1). Reagents and conditions: a) 19 (1.25 eq), $\mathrm{Pd}\left(\mathrm{PPh}_{3}\right)_{4}(10 \mathrm{~mol} \%), \mathrm{TlOEt}(1.5 \mathrm{eq}), \mathrm{THF}, \mathrm{H}_{2} \mathrm{O}, 0{ }^{\circ} \mathrm{C}$ to rt, $30 \mathrm{~min}$, quant.; b) 20 (2.5 eq), TCBC, Et 3 N, THF; DMAP, PhMe, 68\%; c) Grubbs II (20 mol\%), PhMe, $\left.100{ }^{\circ} \mathrm{C}, 2 \mathrm{~h}, E, E / E, Z=2.7: 1 ; \mathrm{d}\right) \mathrm{NaOMe}, \mathrm{MeOH}, \mathrm{Et} 2 \mathrm{O}, 2 \mathrm{~h}, 91 \%$ (2 steps); e) TMSCl, imid., $\mathrm{CH}_{2} \mathrm{Cl}_{2}, 0{ }^{\circ} \mathrm{C}, 15 \mathrm{~min}, 53 \%$; f) $\mathrm{AcOH}, \mathrm{MeOH}, 5 \mathrm{~h}$, quant;; g) 17 (1.5 eq), TBSOTf (15 mol\%), $\mathrm{CH}_{2} \mathrm{Cl}_{2}, \mathrm{rt}, 15 \mathrm{~min}, 42 \%$; h) NaOMe, $\mathrm{MeOH}, \mathrm{Et}_{2} \mathrm{O}, 14 \mathrm{~h}$; i) $3 \mathrm{HF} \cdot \mathrm{NEt}_{3}$, THF, $50{ }^{\circ} \mathrm{C}, 24 \mathrm{~h}, 80 \%$ (2 steps); j) TCEP, phosphate buffer, THF, $\mathrm{MeOH}, 2 \mathrm{~N} \mathrm{NaOH}, \mathrm{H}_{2} \mathrm{O}, 2$ days; $37 \%$ aq. $\mathrm{CH}_{2} \mathrm{O}, \mathrm{NaBH}_{3} \mathrm{CN}$, $\mathrm{H}_{2} \mathrm{O}, \mathrm{MeCN}, 1 \mathrm{~h}, 25 \%$ (2 steps). Pin = pinacolato, THF = tetrahydrofuran, TCBC $=2,4,6$-trichlorobenzoyl chloride, TMSCl $=$ chlorotrimethylsilane. TBSOTf $=$ tert-butyldimethylsilyl trifluoromethanesulfonate, TCEP $=$ tris $(2$-carboxyethyl)phosphine hydrochloride.

Next, the acetyl and TBS groups were cleaved to give tetraol 24. Finally, reduction of the azide group by TCEP followed by reductive amination and purification by reversed-phase HPLC afforded fully synthetic mangrolide (1). The NMR spectra of the formate adduct (2 equiv.) of the synthetic material 1 matched those reported for the natural product. ${ }^{[2,4]}$

With synthetic (+)-mangrolide A (1) and the derivative $\mathbf{2 4}$ in hand, we began testing against a panel of bacteria (see also the Supporting Information). ${ }^{[2,4]}$ As outlined in Table 1, while for natural 1 low micromolar activity had been reported, ${ }^{[2,4]}$ synthetic 1 did not show any activity against the reference isolates and clinical strains tested. There was no activity against a laboratory-generated mutant of $E$. coli with increased permeability ( $\square r f a C$ ) and decreased efflux ( $\square$ tolC). The spectrum and the activity of fidaxomicin (2) was essentially as reported. ${ }^{[25]}$

Table 1. Minimal inhibitory concentrations of mangrolide A and derivatives against Gram-positive and Gram-negative bacterial strains ${ }^{[a]}$

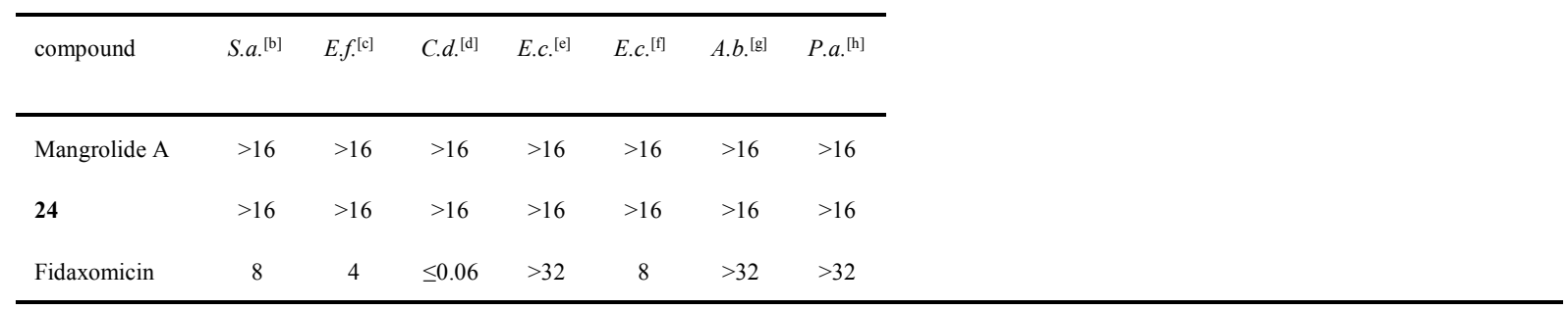

[a] Bacterial isolates are from the Idorsia strain collection. Minimal inhibitory concentrations (MICs, in $\mu \mathrm{g} / \mathrm{ml}$ ) were determined by the broth micro-dilution method according to guidelines of the Clinical and Laboratory Standards Institute (CLSI). ${ }^{[26]}$ [b] S.a.; Staphylococcus aureus ATCC 29213. [c] E.f.; Enterococcus faecalis ATCC 29212. [d] C.d.; Clostridium difficile ATCC 70057. [e] E.c.; Escherichia coli ATCC 25922. [f] E.c.; Escherichia coli 2085 (ArfaC $\Delta$ tolC). [g] A.b.; Acinetobacter baumannii A-1305. [h] P.a.; Pseudomonas aeruginosa ATCC 27853.

As the bacterial strains used in the literature may be more susceptible than the ones described herein, we decided to perform an enzyme assay to investigate the proposed mechanism of inhibition and in vitro potency (Table 2). Mangrolide A (1) and derivatives were tested in a coupled E. coli S30 in vitro transcription/translation (IVTT) assay. Mangrolide A (1) inhibited the translation with equal potency also when a phage promoter was used, just as the erythromycin positive control did, but in contrast to fidaxomicin (2), where the inhibition transcription was dependent on a bacterial promoter. We therefore concluded that mangrolide A (1) inhibits protein translation as previously described. However, the $\mathrm{IC}_{50}$ value was $50-100$-fold higher than the ones determined for erythromycin or fidaxomicin, which may explain the absence of antibacterial activity. Comparing the in vitro activity of $\mathbf{1}$ to $\mathbf{2 4}$ it also became apparent that the $N, N$-dimethylamino group plays a key role for biological activity. The reason for the discrepancy of the observed to the reported biological activity for compound $\mathbf{1}$ remains unclear, contamination by a highly active minor constituent in the natural product would present an explanation. ${ }^{[27]}$ 
Table 2. Activities in E. coli cell-free transcription and translation assay (IVTT) ${ }^{[a]}$

\begin{tabular}{lcc}
\hline compound & E. coli promoter & SP6 promoter \\
\hline Mangrolide A & 6.45 & 8.31 \\
$\mathbf{2 4}$ & 80.8 & $\mathrm{ND}$ \\
Erythromycin & 0.09 & 0.05 \\
Fidaxomicin & 0.04 & 76.6 \\
\hline
\end{tabular}

[a] Assay as described ${ }^{[28]}$ with the following modifications to distinguish inhibitors of transcription from inhibitors of translation. $\mathrm{IC}_{50}$ determined using an E. coli S30 extract either in presence of plasmid pBestluc (n E. coli promoter) or in presence of plasmid pSP-luc +NF (phage SP6 promoter) with added phage SP6 RNA polymerase. In experiments using plasmid pBestluc inhibitors of bacterial transcription or translation interfere with the assay, whereas in experiments using plasmid pSP-luc +NF only inhibitors of the bacterial translation can interfere. IVTT $\mathrm{IC}_{50}[\mu \mathrm{M}]$ are averages of two independent experiments. . ND: not determined.

In summary, we have developed a convergent and modular strategy for the first total synthesis of mangrolide A (1) in 25 steps (longest linear sequence). Salient features of this route include a $\beta$-selective glycosylation without neighbouring group assistance to form the disaccharide $(\mathbf{6}+\mathbf{1 4} \rightarrow \mathbf{1 5})$ and another with the highly congested acceptor alcohol $(\mathbf{4}+\mathbf{1 7} \rightarrow \mathbf{2 3})$. We also demonstrated the robustness of the macrocycle preparation from three key components, all of which are accessed within 8 steps from commercially available starting materials. Evaluation of mangrolide A (1) and its analogues against a panel of pathogenic bacteria revealed no antibiotic activity, however, weak inhibition of translation was observed in an in vitro enzyme assay system. The detailed biological study of mangrolide A (1) and synthesis of similar 18-membered natural and unnatural antibiotic candidates is ongoing, and will be disclosed in due course.

\section{Acknowledgements}

We gratefully acknowledge partial financial support by the SNSF. We thank Angela Amsler and Cédric Lüthi for technical support, Simon Jurt for assistance with NMR spectroscopy, and Myriam Gwerder, Jonathan Delers, Hans H. Locher, and Daniela Sabato for antibacterial testing. We further thank Stefan Diethelm and Simon Williams for stimulating discussions.

Keywords: natural products $\bullet$ antibiotics $\bullet$ carbohydrate chemistry $\bullet$ stereoselective synthesis $\bullet$ glycosylation

[1] WHO 2017.12, Antibacterial agents in clinical development.

[2] M. T. Jamison, PhD thesis, The University of Texas Southwestern Medical Center at Dallas (US), 2013.

[3] D-Mycaminose is found in macrolide antibiotics (e.g. tylosin or carbomycin). Interestingly, the veterinary antibiotic drug, tylosin targets the 50S ribosomal subunit and inhibits translation, which implies a different mechanism of action to mangrolide A (1). a) J. M. McGuire, W. S. Boniece, C. E. Higgens, M. M. Hoehn, W. M. Stark, J. Westhead, R. N. Wolfe, Antibiot. Chemother. 1961, 11, 320-327; b) R. B. Woodward, Angew. Chem. 1957, 69, 50-58; c) R. B. Woodward, L. S. Weiler, P. C. Dutta, J. Am. Chem. Soc. 1965, 87, 4662-4663; d) P. Constable, K. W. Hinchcliff, S. Done, W. Gruenberg, Veterinary Medicine (Elsevier) 11th ed. 2017, pp. 153-174.

[4] J. DeBrabander, PCT/US2015/030621, 2015.

[5] I. Artsimovitch, J. Seddon, P. Sears, Clin. Infect. Dis. 2012, 55, 127-131.

[6] a) H. Miyatake-Ondozabal, E. Kaufmann, K. Gademann, Angew. Chem. Int. Ed. 2015, 54, 1933-1936; Angew. Chem. 2015, 127, 1953-1956; b) E. Kaufmann, H. Hattori, H. Miyatake-Ondozabal, K. Gademann, Org. Lett. 2015, 17, 3514-3517; c) F. Glaus, K. H. Altmann, Angew. Chem. Int. Ed. 2015, 54, 1937-1940; Angew. Chem. 2015, 127, 1957-1961; d) W. Erb, J. M. Grassot, D. Linder, L. Neuville, J. Zhu, Angew. Chem. Int. Ed. 2015, 54, 19291932; Angew. Chem. 2015, 127, 1949-1952; e) L. Jeanne-Julien, G. Masson, E. Astier, G. Genta-Jouve, V. Servajean, J. M. Beau, S. Norsikian, E. Roulland, Org. Lett. 2017, 19, 4006-4009; f) H. Hattori, E. Kaufmann, H. Miyatake-Ondozabal, R. Berg, K. Gademann, J. Org. Chem. DOI 10.1021/acs.joc.8b00101; g) L. Jeanne-Julien, G. Masson, E. Astier, G. Genta-Jouve, V. Servajean, J.-M. Beau, S. Norsikian, E. Roulland, J. Org. Chem. 2018, 83, 921-929.

[7] a) K. Kitamura, Y. Maezawa, Y. Ando, T. Kusumi, T. Matsumoto, K. Suzuki, Angew. Chem. Int. Ed. 2014, 53, 1262-1265; Angew. Chem. 2014, 126, 1286-1289; b) I. Smith, E. N. Pitsinos, C. K. Hwang, Y. Mizuno, H. Saimoto, G. R. Scarlato, T. Suzuki, K. C. Nicolaou, J. Am. Chem. Soc. 1993, 115, 7625-7635; c) K. C. Nicolaou, Z. Lu, R. Li, J. R. Woods, T. I. Sohn, J. Am. Chem. Soc. 2015, 137, 8716-8719; d) S. A. Hitchcock, M. Y. Chu-Moyer, S. H. Boyer, S. H. Olson, S. J. Danishefsky, J. Am. Chem. Soc. 1995, 117, 5750-5756.

[8] a) A. G. Myers, J. Liang, M. Hammond, P. M. Harrington, Y. Wu, E. Y. Kuo, J. Am. Chem. Soc. 1998, 120, 5319-5320; b) K. Tatsuta, Y. Amemiya, Y. Kanemura, H. Takahashi, M. Kinoshita, Tetrahedron Lett. 1982, 23, 3375-3378; c) S. L. Gholap, C. M. Woo, P. C. Ravikumar, S. B. Herzon, Org. Lett. 2009, 11, 4322-4325; d) H.-S. Oh, R. Xuan, H.-Y. Kang, Org. Biomol. Chem. 2009, 7, 4458-4463.

[9] Reviews in antibiotic natural product synthesis: a) K. Toshima, Carbohydr. Res. 2006, 341, 1282-1297; b) S. E. Rossiter, M. H. Fletcher, W. M. Wuest, Chem. Rev. 2017, 117, 12415-12474.

[10] Given the incompatibility of azide with the macrocycle forming events (e.g. Suzuki Coupling and RCM), we planned to introduce the disaccharide moiety after cyclizing the ring; an example of azidodisaccharide on macrocyclic natural product synthesis: A. M. Szpilman, E. M. Carreira, Org. Lett. 2009, 11, 1305-1307.

[11] K. K. -K. T. Mong, T. Nokami, N. T. T. Tran, P. B. Nhi in Selective Glycosylations: Synthetic Methods and Catalysts. (Ed.: C. S. Bennett), Wiley-VCH, Weinheim, 2017, pp. 59-77.

[12] H. Guo, G. A. O'Doherty, Angew. Chem. Int. Ed. 2007, 46, 5206-5208; Angew. Chem. 2007, 119, 5298-5300.

[13] a) D. Icheln, B. Gehrcke, Y. Piprek, P. Mischnick, W. A. König, M. A. Dessoy, A. F. Morel, Carbohydr. Res. 1996, 280, $237-250$.

[14] N. Tanaka, I. Ogawa, S. Yoshigase, J. Nokami, Carbohydr. Res. 2008, 343, 2675-2679. 
[15] P. J. Garegg, R. Johansson, B. Samuelsson, Synthesis, 1984, 189-195.

[16] The use of MeI, NaH, THF or $\mathrm{Me}_{2} \mathrm{SO}_{4}, \mathrm{NaH}$, THF led to the migration of the TBS group. $\operatorname{Ag}_{2} \mathrm{O}, \mathrm{MeI}$ (neat), at reflux gave no reaction.

[17] M. P. Croatt, E. M. Carreira, Org. Lett. 2011, 13, 1390-1393.

[18] a) T. Mukaiyama, H. Jona, Proc. Japan Acad. Ser. B, Phys. Biol. Sci. 2002, 78, 73-83; b) L. Bohé, D. Crich in Selective Glycosylations: Synthetic Methods and Catalysts. (Ed.: C. S. Bennett), Wiley-VCH, Weinheim, 2017, pp. 115-133; c) S. Hashimoto, Y. Yanagiya, T. Honda, H. Harada, S. Ikegami, Tetrahedron Lett. 1992, 33, 3523-3526; d) T. Tsuda, R. Arihara, S. Sato, M. Koshiba, S. Nakamura, S. Hashimoto, Tetrahedron 2005, 61, 10719-10733; e) J. Mlynarski, J. Ruiz-Caro, A. Fürstner, Chem. Eur. J. 2004, 10, 2214-2222; f) P. Peng, R. R. Schmidt, J. Am. Chem. Soc. 2015, 137, 12653-12659.

[19] B. Yu, J. Sun, Chem. Commun. 2010, 46, 4668-4679.

[20] K. Takeuchi, T. Mukaiyama, Chem. Lett. 1998, 555-556.

[21] I. Krossing, I. Raabe, Angew. Chem. Int. Ed. 2004, 43, 2066-2090.

[22] a) K. Takeuchi, T. Tamura, T. Mukaiyama, Chem. Lett. 2000, 29, 124-125; b) S. I. Tanaka, M. Takashina, H. Tokimoto, Y. Fujimoto, K. Tanaka, K. Fukase, Synlett 2005, 2325-2328.

[23] See supporting information for the synthesis. The stereogenic center was constructed either by Jacobsen's hydrolytic kinetic resolution (HKR) or using (+)valine. a) M. Tokunaga, J. F. Larrow, F. Kakiuchi, E. N. Jacobsen, Science 1997, 277, 936-938; b) T. Taguri, M. Yamamoto, T. Fujii, Y. Muraki, T. Ando, Eur. J. Org. Chem. 2013, 6924-6933.

[24] The glycosyl bromide used in the fidaxomicin synthesis was very unstable and there was a mismatch in reactivity between glycosyl donor and accepter.

[25] a) E. J. C. Goldstein, F. Babakhani, D. M. Citron, Clin. Infect. Dis. 2012, 55, 143-148; b) E. J. Goldstein, D. M. Citron, K. L. Tyrrell, C. V. Merriam. Antimicrob Agents Chemother. 2013, 57, 4872-4876.

[26] CLSI document M07-A9, Clinical Laboratory Standards Institute, Wayne, PA, USA; 2012.

[27] Recent example of 'inactive' natural products: a) M. T. Villaume, E. Sella, G. Saul, R. M. Borzilleri, J. Fargnoli, K. A. Johnston, H. Zhang, M. P. Fereshteh, T. G. M. Dhar, P. S. Baran, ACS Cent. Sci. 2016, 2, 27-31; b) A. Cernijenko, R. Risgaard, P. S. Baran, J. Am. Chem. Soc. 2016, 138, 9425-9428; c) M. Moreno, W. A. M. Elgaher, J. Herrmann, N. Schläger, M. M. Hamed, S. Baumann, R. Müller, R. W. Hartmann, A. Kirschning, Synlett 2015, 26, 11751178

[28] H. H. Locher, P. Caspers, T. Bruyère, S. Schroeder, P. Pfaff, A. Knezevic, W. Keck, D. Ritz. Antimicrob Agents Chemother. 2014, 58, 901-908. 